eases of children. There may also be some variation in the practice of returning a birth and death instead of a still-birth, though this wonld be more likely to tell the other way. In any case, there is matter for consideration.

I have the honour to be, Sir,

Your obedient Servant,

13, Brompton Row, CHARLES W. MERRIFIELD. $12 t h$ February, 1856.

\title{
ON THE COMPARATIVE VALUE OF GOLD IN DIFFERENT COUNTRIES.
}

To the Editor of the Assurance Magazine.

SrR,-Referring to Notes and Queries, in Assurance Magazine, No. XXII., pp. 104, 105, on the subject of "Comparative Value of Gold in different Countries," there is a mistake in the statement that "one kilogramme of fine gold (or $32 \cdot 154$ ounces) is valued, at par, at $3434 \cdot 4 \dot{4}$ francs." This was never, unless I am misinformed, the par value. The par value, according to the French Mint regulations of 6 June 1803, 1 July 1835 , and 1 October 1849 , has uniformly been $3444 \cdot 44 \dot{4}$ francs; and the net French Mint value, after deduction allowed for cost of coinage, \&c., although it was $3434 \cdot 4 \dot{4}$ by the tariff of 6 June 1803 (17 Prairial, an xi.), ceased to be so since the tariff of $1 \mathrm{July} 1835$, and became $3437 \cdot 7 \dot{7}$ francs.

I cannot understand why the metal silver is brought into the gold calculation of the Magazine statement. I submit the following for the favour of your consideration, whether they be not the true conditions of the problem rather than those given in the statement referred to:-

1. One ounce English of standard gold, of $\frac{11}{12}$ fine, $=£ 3.89375$.

2. One kilogramme French (or $32 \cdot 154$ ounces English) of fine gold is, according to French Mint regulations, of the net value of $3437 \cdot 7 \dot{7}$ francs.

3. At 4 per mille premium, being the current agio of the day, 1000 francs Mint value of gold $=1004$ francs.

Then we have $\frac{1 \times 11 \times 3437 \cdot 77 \times 1004}{3 \cdot 89375 \times 12 \times 32 \cdot 154 \times 1000}=\frac{37966809 \cdot 188}{1502395 \cdot 65}=$ $25 \cdot 27$ francs (as per the above conditions, and not $25 \cdot 25$ as per the statement before mentioned).

Shorter ways suggest themselves for a general method, applicable to any given agio per mille; but all dependent on the same rationale upon which the calculation just given in detail must always rest, so long as the currency regulations of the two countries, England and France, remain as they now are with respect to the appreciation of gold.

I remain, Sir,

Yours always truly,

Globe Insurance, Cornhill, FREDERICK HENDRIKS.

London, 22 January, 1856.

Notr. -We are much obliged to our correspondent for his correction of the statement as to the Mint price of gold in France. We were not aware 
of the alteration he speaks of in 1835 . The rule by which he determines the rate of exchange we of course knew, and it was that we alluded to as being unintelligible to ordinary readers. His not understanding why silver is brought into the gold calculation we are surprised at-he himself introduces it when he speaks of francs; and it must, we think, be obvious, that the introduction of some such measure is indispensable. The variations in the price of gold or of any other commodity cannot with any degree of consistency be expressed in terms of the commodity itself. An ounce of gold can, never be worth more or less than an ounce of gold.-ED. $A . M$.

\section{ON THE SAME SUBJECT.}

To the Editor of the Assurance Magazine.

Sir,-In reply to your note, appended to my communication of the 22nd ultimo:

You state you are surprised at my not understanding why silver is brought into the calculation.-To this I answer, that silver has no more to do with the calculation than corn, lead, or tin.

You observe, that I myself introduce it (i.e., silver) when I speak of francs. Here $I$ join issue, and require to be instructed that there are no such things as gold legal tender francs, as well as silver legal tender francs.

You make the interpellation, that the introduction of some such (silver) measure is indispensable.-This I cannot concur in. What we want, and what the daily papers properly show, by their method which in my former communication I tried to defend, is the real comparative value of gold, in one country or place, as measured by its value in another country or place.

The theoretical or intrinsic par of exchange between two places is the metallic equation or comparison of the respective ratios in which the pure metal exists in any given weight of Mint coinage of the same metal at the two places.

When we talk of the par of exchange between England and France, our comparison should be between gold money of England and gold money of France. By so doing we ascertain that 10,000 English gold sovereigns are equal to 252,079 French gold francs, the weight of pure gold in the former being equal to the weight of pure gold in the latter.

Thus we arrive at the normal par of exchange between the two countries-viz., $\mathfrak{f} 1=\mathbf{2 5} \cdot 2079$ francs. But this estimate is based on weight of metal, not on its comparative value, and therefore is no verification of your remark, that "an ounce of gold can never be worth more or less than an ounce of gold." The question as to the worth of an ounce of gold is never entertained in such an estimate.

The fluctuating commercial par of exchange-i.e., the real exchangeable value for the time being-is quite another matter, and, as I still consider, is estimated correctly by the method of the daily papers in the case of gold-viz., by comparison of its value in this country (as affected by our Mint regulations and our market price of gold) with the value in another country (as affected by its Mint regulations and its market price of gold).

Under such conditions, and the countries for comparison being England and France-the premium on gold being 4 per mille in the latter country, and the Mint regulations of the two countries being as pointed ont in my 